\title{
A new record of Genus Icius Simon, 1876 for Jumping Spiders (Araneae: Salticidae) of Pakistan
}

\author{
Pir Asmat Ali* \\ Department of Zoology, Women University Swabi, Swabi, Pakistan. \\ * Corresponding Author Email: pirasmat85@gmail.com
}

Published Online: December 17, 2021

\begin{abstract}
The research studies on the jumping family of Salticidae in Pakistan are rare due to several reason. In this study, I present the first record of Icius alboterminus (Caleb, 2014) from Pakistan. Specimen for the study is collected selected area of district Swabi, Pakistan. The findings of the study constitute the first record of genus Icius Simon, 1876 from the country, as well as an updated distribution map is presented in this study as well.
\end{abstract}

Keywords: Salticidae, Icius, Icius alboterminus (Caleb, 2014), Genus Icius, distribution map, new record.

\section{How to Cite:}

Ali, P. A. (2021). A new record of Genus Icius Simon, 1876 for Jumping Spiders (Araneae: Salticidae) of Pakistan. Natural \& Applied Sciences International Journal (NASIJ), 2(1), 80-86. https://doi.org/10.47264/idea.nasij/2.1.7

\section{Publisher's Note:}

IDEA PUBLISHERS (IDEA Journals Group) stands neutral regarding jurisdictional claims in the published maps and institutional affiliations.

\section{Copyright:}

(C) 2021 The Author(s), published by IDEA PUBLISHERS (IDEA Journals Group)

\section{Licensing:}

This is an Open Access article published under the Creative Commons Attribution-NonCommercial 4.0 International License (http://creativecommons.org/licenses/by-nc/4.0/) 


\section{Introduction}

The jumping spiders of family Salticidae of Pakistan has never been the subject of intensive taxonomic studies because of two reasons lack of taxonomic knowledge and inappropriate curation of the specimens. Only few works with a few species reported to date (Ali et al. 2018; Ali et al. 2016; Azarkina 2004; Bauer et al. 2015; Caleb et al. 2019; Logunov 2021; Logunov 2020; Logunov and Azarkina 2018; Logunov et al. 2011; Wesołowska and Freudenschuss 2012). However, an ongoing project to discover the country's salticid diversity is revealing that many species are present, especially of species Palearctic, African and oriental regions distributed in Pakistan.

The Genus Icius simon, 1876 members are represented worldwide except Australia. This paper presents, (a) first new record of genus Icus to Pakistan, (b) the first record of Icius alboterminus (Caleb 2014) outside its type of locality India (Caleb 2017; Parapati and Kambo 2020).

\section{Materials and methods}

The specimens were collected from subtropical srub mountain in districts Swabi and observed the stereomicroscope in $70 \%$ alcohol. The species was identified by comparing the literature provided in Caleb (2014) and Caleb (2017). Male genetalia was photographed with digital camera 5MP attached stereomicroscope. Female photographed followed for male. The destribution map of Icius alboterminus (Caleb 2014) is presented (figure 3). Measurements are given in millimeters.

\section{Results and discussion}

\section{Taxonomy}

\section{Gen. Icius Simon 1876}

This genus Icius was erected from type of species Icius hamatus C. L. Koch, 1846. There are 36 species worldwide, of which four species from India, one from Afghanistan and three from China (Caleb 2017; Prajapati et al. 2018; Prajapati and Kamboj 2019; Prajapati et al. 2021; WSC 2021). To date, the genus has not been formally recorded from Pakistan.

\section{Icius alboterminus (Caleb, 2014) (Fig 2-3)}

Specimen Examined:

The speciman examined for the study is of 1 Male, Pakistan, Khyber Pakhtunkhwa, Swabi, Jhanda, (3406'53.1"N 72³3'36.2"E), 560 elevation, 26 August 2018, Pir Asmat Ali, scrub mountains (specimen PAA\# 2018-08-51). 
Diagnosis:

Species different from other congeners by the shape of embolus, retrolateral tibial aphophysis ( Figs. 2 C-D ) and the abdomen dorsal pattern with white setae forming dots on both sexes (Figs. 1 A-B). Males embolus claw shaped and directed to venter at end and RTA elongated (Figs. 2 C-D).

\section{Description: Male (Fig.1; A)}

Total length 2.90; carapace length 1.50 long, width 1.12; abdomen 1.50, 1.05 wide.

The Cephalothorax elongated blackish-brown almost black, with white marginal spines, whitish hairs at anterio-lateral sides. Chelicerae are with one promarginal and one retromarginal teeth. Leg I strongest blackish-brown almost black streak, all other legs yellowish with brown streaks.

Abdomen oval elongated with setae and scales, brownish anteriorly and blackish brown at posterior end; the white dots on abdomen is diagnostic character of the species. Spinnerets blackish.

\section{Description: Female (Fig.1; B)}

Specimen Examined:

Another specimen examined for this is of 1 female, Pakistan, Khyber Pakhtunkhwa, Swabi,

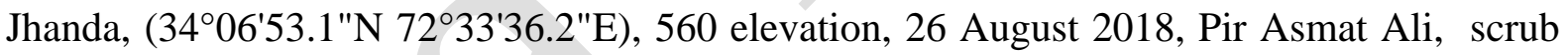
mountains (specimen PAA\# 2018-08-52)

Total length 3.25; carapace length 1.51, width 1.11; abdomen 1.71 length, width 1.22.

The characteristics of female are almost similar with males but differ in brightness, lighter coloration of the body as compared to its male (Fig.1-B).

Icius alboterminus (Caleb, 2014) is currently distributed in Pakistan and India (Fig.3). The salticid spiders of Pakistan need extensive taxonomic work to understand the genera and species distribution in Palearctic and oriental. Moreover, to overcome taxonomic studies gaps, a proper curated museums and taxonomic experts can make great contribution for future work on Salticid spiders exploration. 


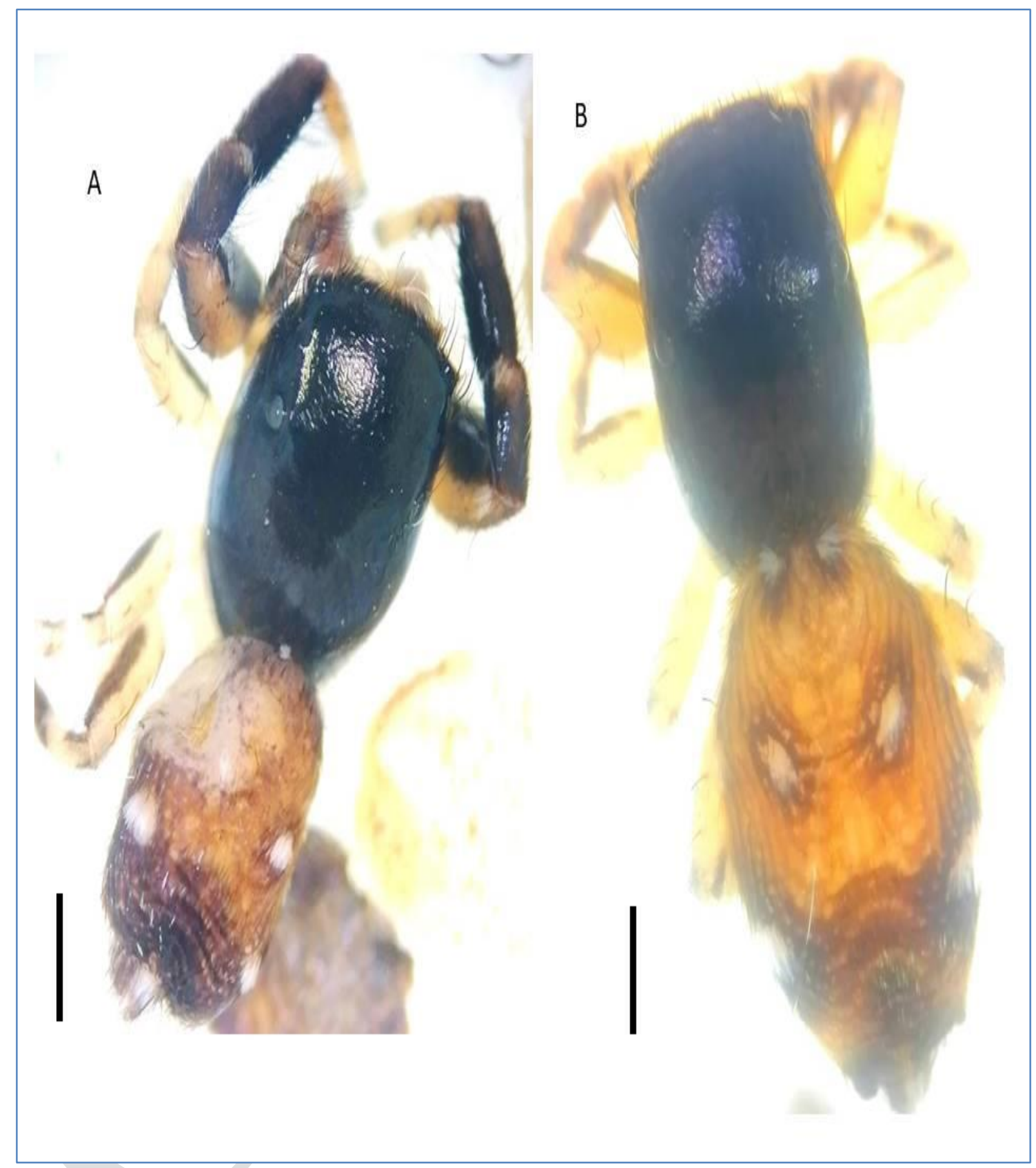

Figure 1 (A-B). Male and female of Icius alboterminus (Caleb, 2014) dorsal view, scale bar $2 \mathrm{~mm}$. 
A new record of Genus Icius Simon, 1876 for Jumping Spiders (Araneae: Salticidae) ...

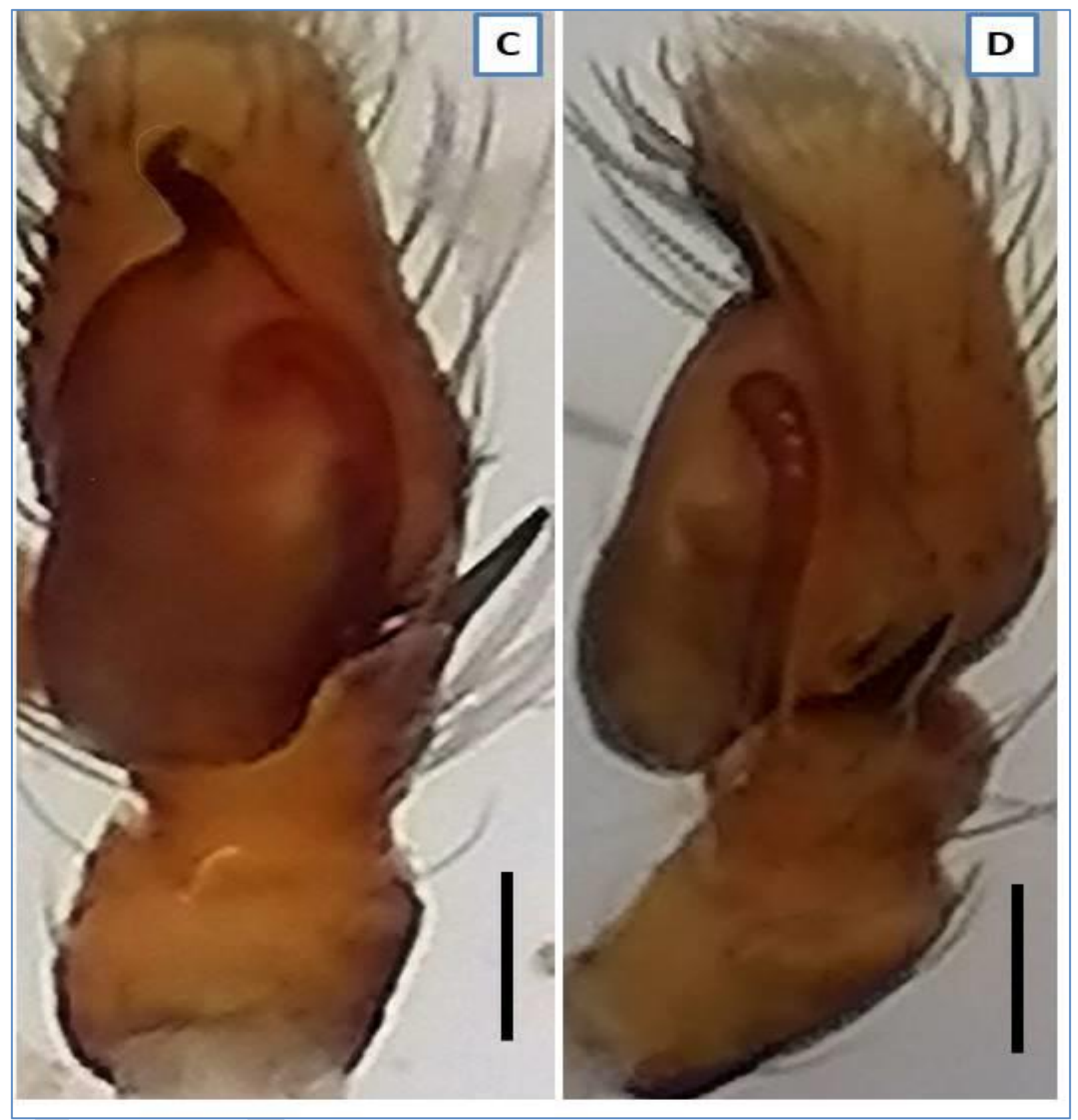

Figure 2 (C-D). Male palp ventral and retrolateral view of Icius alboterminus (Caleb, 2014) 


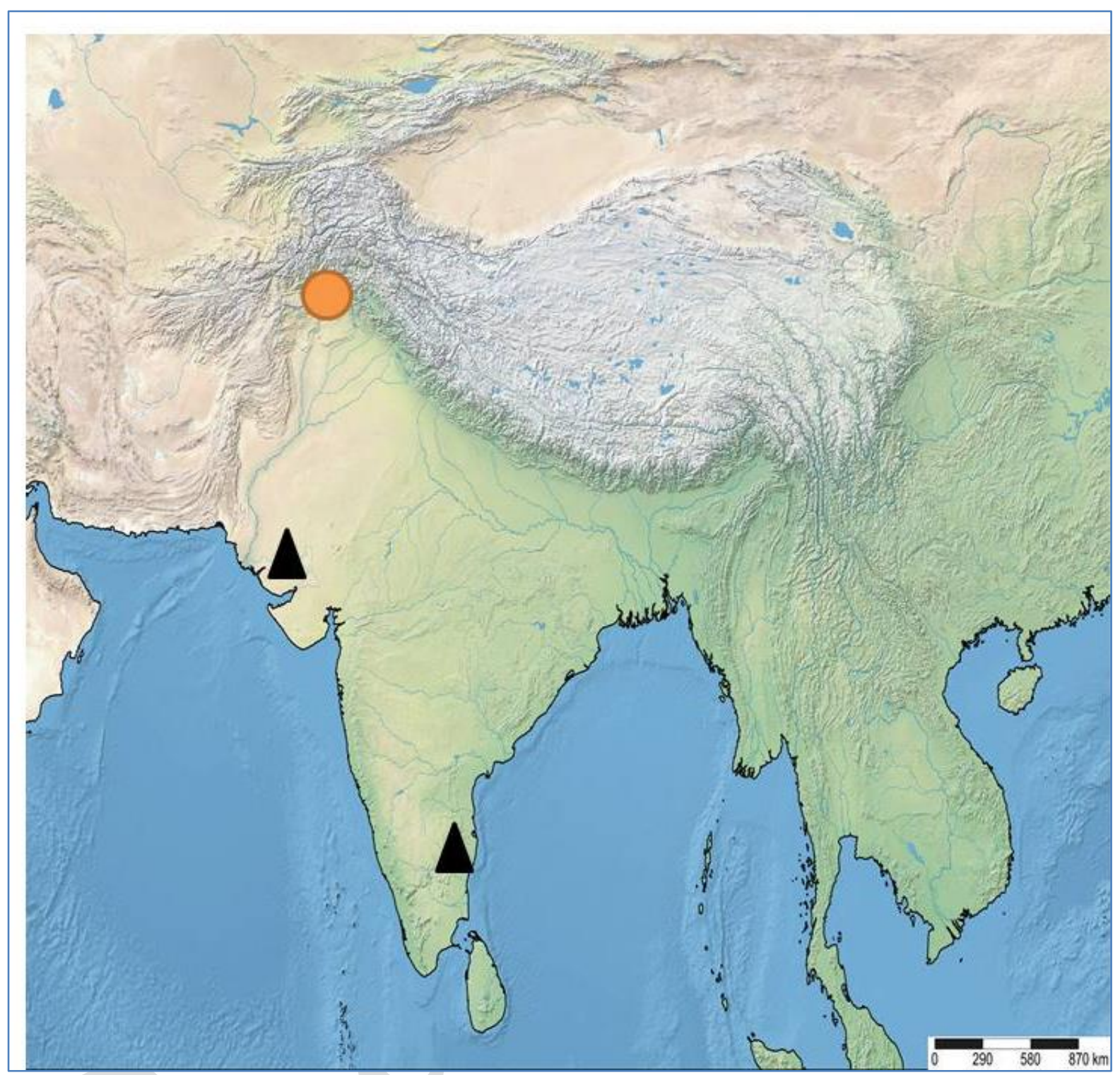

Figure3. Distribution Map of Icius alboterminus (Caleb, 2014) in the subcontinent

\section{Acknowledgement:}

I thankful to Women University Swabi grant for Checklist of spiders of Pakistan on World Wide Web and IUCN. 


\section{References}

Ali, P. A., Maddison, W. P., \& Zahid, M. (2016). Documenting the subtribe Aelurillina from the Hindu Kush region of Pakistan. Denver Museum of Nature and Science Reports 3: 38 .

Ali, P. A., Maddison, W. P., Zahid, M. \& Butt, A. (2018). New chrysilline and aelurilline jumping spiders from Pakistan (Araneae, Salticidae). ZooKeys 783: 1-15.

Azarkina G. N. (2004). Two new species of the genus Aelurillus Simon, 1884 from Pakistan and Sri Lanka (Araneae: Salticidae). Bulletin of the British Arachnological Society 13: 49-52.

Bauer, T., Freudenschuss, M., Grabolle, A. (2015). Plexippoides flavescens (O. PickardCambridge, 1872) and Menemerus marginatus (Kroneberg, 1875), new records for Pakistan (Aranei: Salticidae). Arthropoda Selecta 24: 87-90.

Caleb, J. T. D., Prajapati, D. A. \& Ali, P. A. (2019). Redescription of Rudakius ludhianaensis (Tikader, 1974) (Aranei: Salticidae), with notes on its synonymy and distribution. Arthropoda Selecta 28(3): 417-423.

Caleb, J. T. D. (2014). A new species of Phintella Strand (Araneae: Salticidae) from India. Munis Entomology and Zoology 9(2): 605-608.

Caleb, J. T. D. (2017). Jumping spiders of the genus Icius Simon, 1876 (Araneae: Salticidae) from India, with a description of a new species. Arthropoda Selecta 26(4): 323-327.

Cloutier, S. (2007). Plant Mol Biol. Leaf rust resistance gene Lr1

Logunov, D. V., Ballarin, F., Marusik, Y. M. (2011). New faunistic records of the jumping and crab spiders of Karakoram, Pakistan (Aranei: Philodromidae, Salticidae and Thomisidae). Arthropoda Selecta 20(3): 233-240.

Logunov, D. V. (2021c). Notes on the genus Chinattus Logunov, 1999 from India, Pakistan and Nepal (Arachnida: Araneae: Salticidae). Zootaxa 5006(1): 110-120.

Logunov, D. V. (2021a). On three species of Plexippoides Prószyński, 1984 (Araneae: Salticidae) from the Mediterranean, the Middle East, and Central Asia, with notes on a taxonomic validity of the genus. Arachnology 18(7): 766-777.

Logunov, D. V. (2019). Taxonomic notes on the Harmochirina Simon, 1903 from South and South-East Asia (Aranei: Salticidae). Arthropoda Selecta 28(1): 99-112.

Logunov, D. V. \& Azarkina, G. N. (2018). Redefinition and partial revision of the genus Stenaelurillus Simon, 1886 (Arachnida, Araneae, Salticidae). European Journal of Taxonomy 430: 1-126.

Prajapati, D. A. \& Kamboj, R. D. (2020a). Additional morphological notes on the male of Icius alboterminus (Caleb, 2014) (Aranei: Salticidae) with new distribution records from India. Journal of Threatened Taxa 12(4): 15475-15480.

Simon, E. (1876). Les arachnides de France, vol. 3, Paris, 364pp.

Wesołowska, W. \& Freudenschuss, M. (2012). A new species of Menemerus from Pakistan (Araneae: Salticidae). Genus 23: 449-453.

WSC. (2021). World Spider Catalog. Version 22.5. Natural History Museum Bern. http://wsc.nmbe.ch 